\title{
AGRICULTURAL SOIL SCIENCE
}

\begin{abstract}
WN years have elapsed since the popular Easter School in Agricultural Science was inaugurated at the School of Agriculture in the University of Nottingham. The eleventh meeting, which was held during March 23-26. was marked by a symposium and colloquium on "Experimental Pedology". Some 130 scientists, experts in a wide range of disciplines and assembled from the British Isles, Europe, Israel, the British Commonwealth and the United States, testified to the general interest in soil science and to the particular concern for that aspect of the subject dealing with the genesis, properties and classification of the soil profile.

After a welcome to the University from Mr. B. L. Hallward, the vice-chancellor, the delegates settled down to a programme developing logically from organic geochemistry and the chemistry of rock surfaces through the organic and inorganic agencies of soil profile develop. ment studied in situ, in the laboratory and by model simulating processes, to the final analysis of experimental pedology in relation to soil classification.

The assessment of release and redistribution of major and trace elements in weathering rocks, in the soil profile and of their loss in drainage water has always been at the basis of soil research. The construction of a rough
\end{abstract}

balance sheet from such data can be instructive and informative, but its value is greatly enhanced when the agencies responsible for the changes can be identified qualitatively and quantitatively.

The symposium not only illustrated the enormous wealth of information that exists on the results of soil changes but also the dearth of precise knowledge of the processes and their dynamics. Too little is known of the movement of either simple ions or of more complex substances, nor do we yet know enough about the natural processes of clay formation or of the precise roles of living organisms or their products in the development of soils. Discussion of the kind provided by this School serves an excellent purpose by directing attention to these needs and should serve in turn to kindle the fire of fresh ideas and extend the mind to further effort.

This stimulating and provocative symposium was noteworthy for its unobtrusive yet skilful organization, tribute for which must be paid to Prof. Hallsworth and his many helpers. His forthcoming departure to the Commonwealth Scientific and Industrial Research Organization (Nature, 199, 1237; 1964) carries both our good wishes and thanks for his inspiration of the Schools.

\section{R. I. DAVIES}

\section{BRITISH COAL UTILIZATION RESEARCH ASSOCIATION}

$\mathrm{T}$ HE annual report for 1963 of the British Coal Utilization Research Association*, which includes a list of publications and of staff, records a total staff at the end of the year of 67 scientists, 109 research officers and research assistants, 47 in clerical and administrative grades, and 90 in industrial grades. An extensive survey was completed of the behaviour of a variety of types of coals with a wide range of ash-fusion characteristics, in an attempt to relate coal type and ash composition with the formation of clinker and slag in shell boilers. There was very little clinker formation with any of the coals but sufficient slag on the ignition arch to attempt corelations. The opportunity was taken to investigate the formation of deposits on end-tube plates which, with some coals, can be very troublesome.

In domestic heating, the first of four main programmes was to try to improve the amenities and performance of the conventional central heating boiler fired with smokeless fuel. The second programme is to try to devise a means of burning bituminous coals smokelessly in a central heating boiler; the third, to design a reliable and cheap heat meter; and the fourth, to obtain reliable information on the amount of smoke emitted from domestic appliances for a range of fuels. Investigations of mineral deposits and corrosion in water-tube boilers are increasingly directed to problems which may arise in future in the large power-station boilers operating at very high steam temperatures and pressures. Four proprietary alloy steels of different composition have been tested above $600^{\circ} \mathrm{C}$ in the biggest of the three laboratory. combustors when using a range of coals including the normal test fuel of high chlorine content, and further extensive trials have been carried out on the town-gas-fire combustor.

Much work on slagging gasification during the year has been concerned with filling gaps in the knowledge of slag formation and behaviour and other facets of the operation of the slagging fixed-bed process. Confirmatory laboratory tests in the high-temperature viscometer * The British Coal Utilization Research Association. Annual Report,
1963. Pp. 92 (Leatherhead: The British Coal Utilization Research 1963. Pp. 92. (Leatherhead: The British Coal Utilization Research have shown that, where refractory mineral matter is being dissolved in a slag, the apparent viscosity may attain a value several times that of the viscosity of the homogeneous slag that is finally formed. Investigations have been made into the changes of the chemical composition of slags under particular operating conditions, and particularly of the volatilization of silica and of the loss of iron. Systematic investigation of the slagging properties of the ashes of British coals was completed during the year, and some attention was also directed to the crystallization properties of the slags.

Basic investigations, during the year, of combustion and gasification were directed at exploring the phenomena of pre-ignition heating and the devolatilization of pulverized fuel particles in the laminar flow furnace. Measurement of the thermal conductivities and diffusivities of coals of temperatures up to $900^{\circ} \mathrm{C}$ has been completed. In observing the structure and reactivity of reactor graphites, comparisons have been made of the porous structure parameters measured at high and at room temperatures, and the structure of graphites has been further examined before and after their oxidation. More fundamental investigations of the chemical structure of coals have thrown further light on the distribution of groups containing hydrogen, and particularly the differences in fractions of aromatic hydrogen and of hydrogen in methylene groups in coals of different ranks. A twopronged attack on the mechanism of decomposition in the coking temperature range has been further advanced and, from now on, basic investigations of the physical and chemical structure of coal will be directed more to understanding the reactions that occur in various combustion systems.

Fundamental investigations of simple breakages in commercial mills have been greatly advanced during the year. The examination of the stress distribution in thin particles loaded in a model of a ring-mill using photoelastic techniques shows that the primary failure occurs along lines of maximum tensile stress. The distribution of mineral matter in samples of pulverized fuel has also been examined. 